\title{
Ecology of Anopheles darlingi Root with respect to vector importance: a review
}

Hélène Hiwat ${ }^{1,2^{*}}$ and Gustavo Bretas ${ }^{3}$

\begin{abstract}
Anopheles darlingi is one of the most important malaria vectors in the Americas. In this era of new tools and strategies for malaria and vector control it is essential to have knowledge on the ecology and behavior of vectors in order to evaluate appropriateness and impact of control measures. This paper aims to provide information on the importance, ecology and behavior of An. darlingi. It reviews publications that addressed ecological and behavioral aspects that are important to understand the role and importance of An. darlingi in the transmission of malaria throughout its area of distribution. The results show that Anopheles darlingi is especially important for malaria transmission in the Amazon region. Although numerous studies exist, many aspects determining the vectorial capacity of An. darlingi, i.e. its relation to seasons and environmental conditions, its gonotrophic cycle and longevity, and its feeding behavior and biting preferences, are still unknown. The vector shows a high degree of variability in behavioral traits. This makes it difficult to predict the impact of ongoing changes in the environment on the mosquito populations. Recent studies indicate a good ability of An. darlingi to adapt to environments modified by human development. This allows the vector to establish populations in areas where it previously did not exist or had been controlled to date. The behavioral variability of the vector, its adaptability, and our limited knowledge of these impede the establishment of effective control strategies. Increasing our knowledge of An. darlingi is necessary.
\end{abstract}

\section{Background}

The malaria vector Anopheles darlingi was first described in 1926 by Root and named after Dr. Samuel Taylor Darling (1872-1925), a leading expert in tropical diseases in the early twentieth century. This mosquito species has a wide geographic distribution in South and Central America, stretching from South Mexico to North Argentina, and from the East of the Andes chain to the coast of the Atlantic Ocean [1-4]. In coastal areas its distribution is restricted by the salinity of water [2]. Seasonality in An. darlingi population densities depends on the type and availability of breeding sites; the species is often absent or maintains low densities in regions with a long dry season [5]. Anopheles darlingi has an elaborate history of vector incrimination in South America [2,3,6-8] and its presence has been associated with malaria epidemics, like the one in the Paranápanema River, Brazil, in 1950 [9].

\footnotetext{
* Correspondence: helenehiwat@gmail.com

'Laboratory of Entomology, Wageningen University and Research Centre, PO Box 8031, $6700 \mathrm{EH}$ Wageningen, The Netherlands

Full list of author information is available at the end of the article
}

Studies on the biology and behavior of this mosquito have been relatively few, especially when considering its important role in malaria transmission and its association with severe endemic or epidemic malaria [1-3,10-13].

The malaria situation in the world is changing. Not only is there an increased international effort to control and where possible eliminate malaria (Roll Back Malaria, Millennium Development Goals [14], supported by a changed funding environment, but also ongoing developments have resulted in new tools for malaria and vector control. Current strategies of integrated vector management, including the use of insecticide treated bed nets and indoor residual spraying, may not be sufficient to eliminate malaria transmission in all endemic areas. Considering the long-term challenge of eradication of malaria it is essential to increase knowledge on the ecology and behavior of malaria vectors like An. darlingi, in order to evaluate appropriateness and impact of these strategies $[15,16]$.

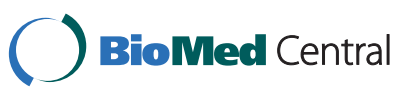

() 2011 Hiwat and Bretas; licensee BioMed Central Ltd. This is an Open Access article distributed under the terms of the Creative Commons Attribution License (http://creativecommons.org/licenses/by/2.0), which permits unrestricted use, distribution, and reproduction in any medium, provided the original work is properly cited. 


\section{Vector importance of An. darlingi in the countries of distribution}

Intensified malaria control activities have led to a decrease in the number of malaria cases in many countries in Latin America. According to the WHO [17], Mexico, El Salvador, Paraguay and Argentina have entered the elimination or pre-elimination phase and only four countries in the Americas, namely Brazil, Colombia, Haiti and Peru, are responsible for $90 \%$ of the malaria in this region in 2009 . Anopheles darlingi is among the most efficient malaria vectors in the Neotropical Region [18]. The exact extent of its distribution is subject to discussion and changes continuously due to ecological changes and adaptations of this mosquito. A predicted distribution based on published records and expert opinions was recently produced by Sinka et al. [8] (Figure 1). The vector importance of $A n$. darlingi varies throughout its area of distribution. In Mexico the main vectors in areas of high transmission risk are Anopheles pseudopunctipennis (inland) and An. albimanus (coastline and marshland). Anopheles vestitipennis is considered a secondary vector [19]. Anopheles darlingi plays a minor role in the south-eastern region of the country $[20,21]$, especially in the state of Oaxaca. Overall malaria in Mexico is down since a change of control strategy towards ecological measures (clearing of vegetation around houses and in waterways) in 1998 [22]. In Guatamala the main vectors are An. albimanus, An. pseudopunctipennis and An. vestipennis, but An. darlingi has been collected along the various river systems $[4,21,23]$ and is considered to play a role in the malaria transmission [24]. The same four vectors play an important role in malaria transmission in Belize and Honduras [18]. In Belize An. darlingi is uncommon in the northern part of the country. In the southern regions it is mostly endophagic, more so than An. albimanus [25]. An interesting study by Roberts et al. [26] shows that in the Toledo District, where $A n$. darlingi was the most common species in the 1940s (based on Kumm \& Ram [27]), no An. darlingi were found in 1992 . Instead, the most abundant mosquito was $A n$. vestitipennis. Malaria transmission in Belize decreased after 1995 as result of a vector control programme with DDT [18]. In Honduras, An. darlingi was a suspected vector in severe malaria transmission in the early $20^{\text {th }}$ century [4]. Sugar-cane and cotton farming have dried up the southern part of the country, which led to a significant decrease of malaria cases and a move of the human population to the north. The resulting forest clearing in the north, however, has led to an increase of malaria in that area due to An. albimanus [18,28].

The incidence of malaria in El Salvador is among the lowest in the Central American countries. Anopheles darlingi specimens have been found [21], but transmission is considered due mainly to An. albimanus and An. pseudopunctipennis, as is the case in Nicaragua where malaria transmission was high but is decreasing $[29,30]$. The northern and eastern regions still have a high transmission risk [31]. Nicaragua and Costa Rica have no collection data of $A n$. darlingi despite numerous and comprehensive surveys in the area trying to locate it. Official reporting of An. darlingi from Panama did not exist for a long time (although it was one of the first countries worldwide from where successful malaria control was reported [32]). Malaria transmission is considered due to An. albimanus and An. punctimacula, which are the most abundant species with the highest human biting rate. Anopheles aquasalis is suspected of playing a role in transmission on the eastern Atlantic coast. Recent genetic studies suggest a long and stable population of $A n$. darlingi in (eastern) Panama, possibly originating from Colombia [33,34]. In Colombia, $A n$. darlingi is the principal malaria vector in the Llanos Orientale, The Amazonia, The Orinoquia, Urubai, Bajo Cauca and Magdalena Media [35]. The most important vector in Colombia is An. albimanus, representing 99\% of the Anopheles population along the Pacific coast and $61 \%$ of the population along the Atlantic coast [36]. Venezuela has a very diverse Anopheles population. Anopheles darlingi is especially important in the Amazonian south along the rivers $[6,37,38]$. Studies by Moreno et al. $[13,39]$ showed that $A n$. darlingi represented over $30 \%$ of the Anopheles populations in locations in the Amazonias and Bolivar state. Other important vectors are $A n$. aquasalis (north east coast), An. albimanus (coast and subcoastal areas), An. pseudopunctipennis (Andes foothills) and An. nuneztovari (northwest) [18]. Vector control with DDT between the 1940s and 1960s proved very efficient in reducing malaria in the Guianas (Guyana, Suriname, French Guiana), eliminating it from the coastal areas of Guyana (1951) and Suriname (1968) [37,40,41]. Anopheles darlingi is considered the most important and often only malaria vector in the sparsely populated interiors of the three countries which are covered with rainforest [6,39,41-45]. Hudson [46], for instance, found that females of $A n$. darlingi were the commonest (98.6\%) of the 5,464 anophelines he collected in the rainforest of Suriname during 1979-1981. In 1980 malaria re-appeared in the coastal area of Guyana and transmission continues among the inland Amerindians $[18,40]$. Despite the resurgence of malaria in the early 1990s and the continued high transmission among Amerindian and Maroon populations of the interior, the coast of Suriname is currently still free of malaria. Since 2005 a sharp decline in number of malaria cases is reported following a scale-up of intervention activities [17]. In French Guiana malaria continues to be a problem in the Amerindian populations along the Oyapock and Lawa Rivers and the Maroon population along the Marowijne River. Coastal malaria has disappeared except from import cases due to Haitian and Brazilian immigrants. This malaria is transmitted by $A n$. darlingi, which 


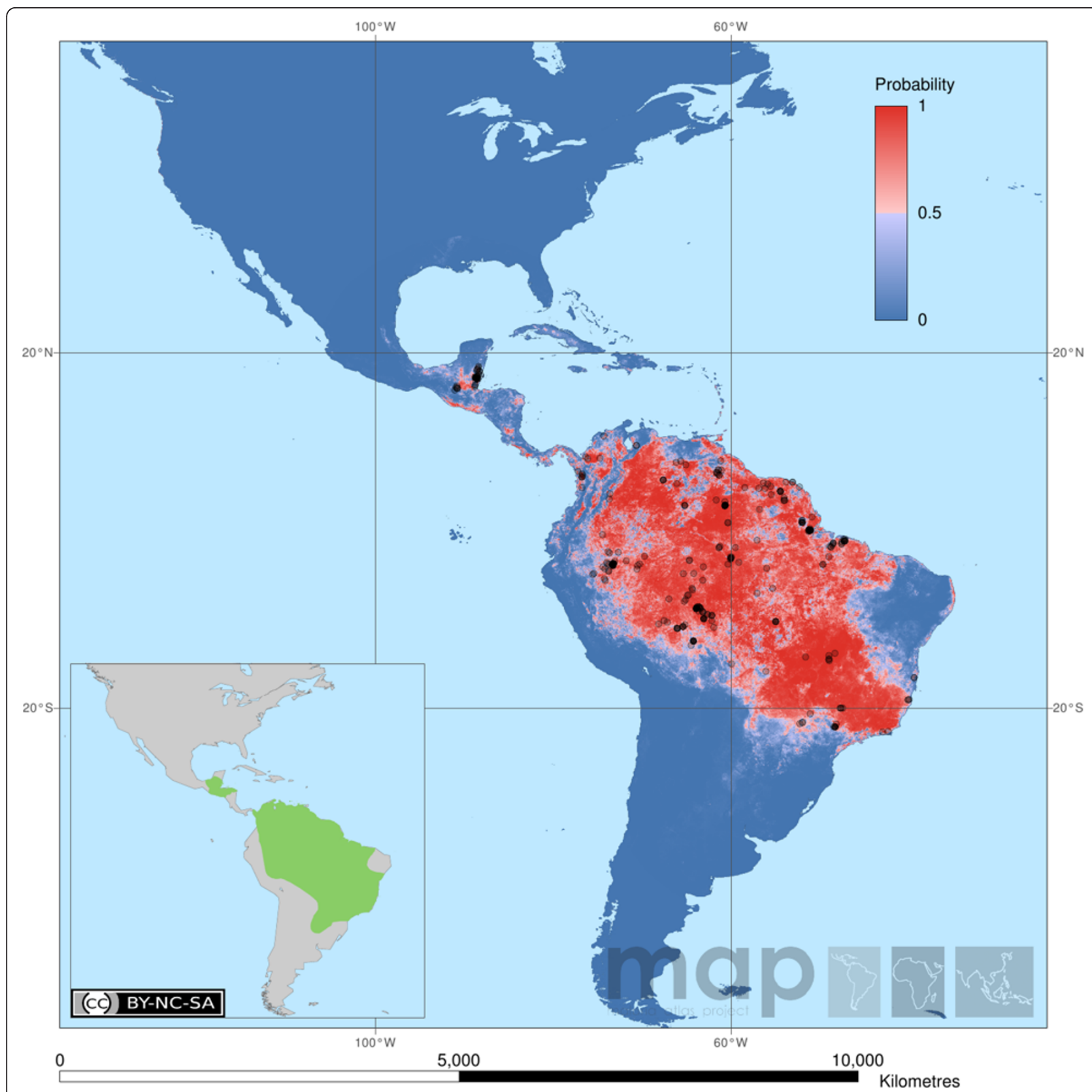

Figure 1 Map of the predicted distribution of Anopheles darlingi. Map by Sinka et al. [7] based on hybrid data (318 occurrence data plus 500 pseudo-presences weighted at half that of the occurrence data and randomly selected from within the Expert Opinion range).

is most likely breeding in coastal swamp areas [18,47]. Almost all cases in Brazil originate from the Brazilian Amazon, with $74 \%$ of the cases coming from the three states Rondonia, Pará and Mato Grosso [18]. Anopheles darlingi is one of the most imporant vectors, with a natural infection rate varying between $2.7 \%$ and $4.2 \%$ in the state of Pará [48]. Other vectors include An. nuneztovari, An. triannulatus, An. oswaldoi, An. albitarsis and An. intermedius. Povoa et al. [49] reconfirmed the importance of An. darlingi in malaria transmission in the savannah eco-region of northern Amazonian Brazil. Here, the species was named an important vector in peri-urban environments.

In Equador fifty percent of the human population lives in malaria endemic areas. Especially in the Amazonian plains, east of the Andes, An. darlingi plays an important role. By contrast, $A n$. albimanus is the main vector along the Pacific coast and An. pseudopunctipennis transmits malaria along the slopes and southern valleys of the Andes [18]. The resurgence of malaria in Peru after 1991 
was thought to be associated with the spread of $A n$. darlingi into new areas of the Amazon Basin [11,50,51]. A study by Schoeler et al. [50] shows that in the departments of Loreto and Ucayali, where over 60,000 mosquitoes were collected, $71 \%$ of the mosquitoes were $A n$. benarrochi and $24 \%$ were $A n$. darlingi. The latter species was found in almost $50 \%$ of the study areas including areas where the species had not been reported before. Flores-Mendoza et al. [12] found positive specimens of both $A n$. benarrochi and An. darlingi at rates of $0.14 \%$ and $0.98 \%$, respectively. In Bolivia, $A n$. darlingi is thought to have played an important role in malaria epidemics in the first half of the $20^{\text {th }}$ century [18]. The species is found in the plains of northeastern Bolivia in the Departments of Beni, Panel and Santa Cruz [52]. Anopheles pseudopunctipennis is an important vector in areas above $500 \mathrm{~m}$. asl. Other vectors include $A n$. nuneztovari, An. triannulatus, An. marajoara and An. braziliensis. Paraguay is a transition area between the Andean countries and Brazil. Areas of moderate malaria risk are found in the Alto Paraná, Caaguazú and Canendiyú, where $P$. vivax is transmitted [31]. Negligible risk exists in the remaining areas. Anopheles darlingi is the only malaria vector reported [18] and its reappearance along the Paraguay border with Argentina is assumed to have been the reason for an increase in malaria on the Argentinean side [53], together with increased border traffic along the Bolivian and Paraguayan border and the ecological changes due to the construction of dams in the Paraná basin. Malaria in the north-western area of Argentina (Satla and Jujuy provinces) is mostly due to An. pseudopunctipennis [54-56]. In the northeastern part (Missiones) An. darlingi is a vector [18].

From the combined studies reviewed above, it is apparent that $A n$. darlingi has a very wide distribution and acts as a malaria vector in almost all South American countries, being the principle vector in the Amazon basin.

\section{Seasonality}

Seasonality patterns of $A n$. darlingi are closely related to the annual cycle of rainfall, although the relation of the occurrence of peak abundances to rainfall patterns seems to differ at different localities or regions. Deane et al. [2] discusses the species' sensitivity to dry season conditions. Rains are thought to increase availability of breeding sites [57] and peak abundances of An. darlingi in the rainy season have been reported [10,58-60]. The local distribution area of $A n$. darlingi may expand during the rainy season, as was observed by Roberts et al. [25] in Belize who found adult females within the range of rivers all year round, but further away from rivers only in the wet season. Forattini [1] found a greater density of $A n$. darlingi during the hot months in southern Brazil and considered that the annual cycle of activity of this species may depend on exogenic factors, including those which can affect the productivity of breeding sites. He considered that the occurrence of heavy rains could possibly flood breeding places and create flood currents that carry away immature forms. This was also found by Pajot et al. [42] in French Guiana who discovered that heavy rains are followed by a decrease in and sometimes a total absence of An. darlingi. This mechanism is thought to have some influence in the increase in the density of $A n$. darlingi in the dry season or in the transitional period between the dry and the wet season $[1,61]$. Following a study in Rondônia (Brazil), Gil et al. [62] make a distinction between malaria of riverine areas and dry land malaria, explaining that differences in the nature and timing of establishment of breeding sites favorable to $A n$. darlingi may result in different ecological models for malaria transmission. In dry land conditions, rivers can flood the margins during the rainy season, but the strong water flow will prevent successful breeding. Only after rains have ended, when rivers retreat to their original size, breeding sites originate as large stable water collections left behind in previously inundated areas. This results in high mosquito densities at the beginning of the dry season and malaria outbreaks in the dry season. By contrast, in riverine areas water levels of the major rivers rise significantly during the rainy season, due to draining from the tributaries. Not only the river margins, but complete forest areas can be flooded, creating inundated forest floors with low water flow which serve as excellent breeding sites for An. darlingi. Peak occurrences will be found in the rainy season, decreasing at the beginning of the dry season, when the flooded forest floors dry up. Such differences in ecological settings may explain a study in Suriname, where Hudson [46] discovered two different seasonal patterns (rainy season peak density and dry season peak density) in areas only $40 \mathrm{~km}$. distant. Rozendaal [63] adds to the evident diversity of seasonal patterns when he finds that peaks in biting densities in a focus of malaria along the Marowijne River in Suriname correlated well with periods of (i) high water level in the long rainy season, (ii) low water level in the long dry season, and (iii) abundant rainfall in the short rainy season. Critical levels of river height and rainfall were defined, which could explain most of the monthly fluctuations in malaria parasite incidence observed in this area. Knowledge about the relationship of An. darlingi with environmental conditions and the impact of seasonal cycles on the mosquito population densities is required to predict areas and seasons of high malaria risk. Considering the large variety of larval habitats of $A n$. darlingi, depending on the (changes in) ecological environments, and considering the adaptability of the vector, there is no way of assessing seasonality of the population densities than through the study of local settings. 


\section{Larval habitats}

Larvae of $A n$. darlingi are thought to require a stable chemical and physical condition in the breeding sites, which is generally not found in small water bodies [2]. This species breeds preferentially in large, deep and clear water collections like lakes, swamps or large rivers $[2,3,10,63]$. Adequate larval conditions depend on depth of the water, temperature, $\mathrm{pH}$, chemical stability and light/shade proportions [3]. A combination of shade and direct sunlight, with a certain amount of cover in the form of vertical vegetation is preferred, with a temperature of $20-28^{\circ} \mathrm{C}$, and a $\mathrm{pH}$ 6.5-7.3 [3,57]. Singer and Castro [64] considered the forest margins to be the principal breeding sites for $A n$. darlingi in the Amazon. Undisturbed forests rarely provide ideal breeding sites due to a high acidity of the water and an absence of partly shaded water bodies. Black rivers with a $\mathrm{pH}$ below 5 and with little vegetation or plankton are unsuitable breeding sites, but Giglioli [57] found how intense rainfall created adequate breeding conditions by diminishing the acidity of black water rivers and by creating clear water swamps in areas where the water bodies had a low $\mathrm{pH}$ or high salinity. Rozendaal [41] collected $A n$. darlingi larvae in water from at a temperature of $40^{\circ} \mathrm{C}$, which contradicts the consideration that the breeding sites are always in cool waters [2]. This has implications for the range of possible breeding sites for this species, especially when considering ecological changes due to for instance deforestation, dam construction or mining. Vittor et al. [65] found that mosquito breeding sites with $A n$. darlingi larvae have an average of $24 \%$ forest cover, compared with $41 \%$ for sites without A. darlingi. Further analysis of breeding-site characteristics identified seasonality, presence of algae, size of water body, presence of human populations, and the amount of forest and secondary growth as significant determinants of $A$. darlingi presence. Larvae are generally found around trunk, emergent plants and floating debris $[7,46,63,66]$, which seems to provide them with some amount of shadow and a stability of water condition in terms of water flow in this particular microhabitat.

Table 1 provides an overview of the various breeding sites of $A n$. darlingi. When breeding in the large sites, $A n$. darlingi larvae seem to prefer deeper areas, away from the edges. This is an important consideration as it causes difficulty for larval surveillance, which may lead to biased information on larval presence and population densities.

\section{Vectorial Capacity}

According to Dean [2]An. darlingi is capable of maintaining a relatively high transmission of malaria even when found in low densities. The mosquito species is considered a good vector, despite its infection rates tending to be low, even in high risk malaria areas. The re-emergence of malaria in eastern Peru is for instance attributed to the spread of $A n$. darlingi into new areas, but the vector infection rate found was less than one percent $[12,50]$. In studies in the high-malaria risk area Rondônia in Brazil by Tadei [7] and Oliveira- Ferreira et al. [67], an infection rate in $A n$. darlingi of $0.48 \%$ (one positive out of 210 and 47 positive out of 9,838 , respectively) was found. Gil et al. [62] also found a low infection rate and considered that An. darlingi, which is the primary vector in that area, maintains malaria transmission by its high human biting rate and that transmission is supported through the high number of asymptomatic malaria cases in the human population. Anopheles darlingi has a relatively high susceptibility to Plasmodium infection when compared to other Amazonian species [68], and asymptomatic cases with very low parasitemias can be infective to $A n$. darlingi, even if it is at a much lower rate than symptomatic cases [69]. The recent discovery of sub-microscopic, but highly infectious, low-density gametocytes of Plasmodium falciparum may be an additional explanation for the relatively continuous infections in the Amazon [70]. Mosquito infection rate can be relatively high at times [48]. Da Silva Vasconcelos et al. [71] found 8.5\% of over $700 \mathrm{An}$. darlingi collected in Roirama (Brazil) to be infected with a Plasmodium parasite. This rate would be comparable to infection rates found for instance for $A n$. gambiae and An. funestus in Tanzania (11.1\% and 6.2\% respectively [72]).

Gonotrophic cycle, longevity and age composition are considered important vector characteristics that are essential in determining the ability to transmit malaria. Based on the view that the gonotrophic cycle in other tropical anophelines lasts approximately three days $[61,73]$ calculated a daily mortality of $A n$. darlingi at Arapuaña, Brazil, of approximately $38 \%$. He considered that only those females that had completed four or more cycles would be old enough to contain malaria sporozoites [74]. Of 1,596 dissected females in his study, only seven had laid eggs four times or more, resulting in a proportion of females that could be potentially infective with malaria sporozoites of $0.4 \%$. In reality the gonotrophic cycle of $A n$. darlingi may be two rather than three days [75], which means that the daily mortality at Arapuaña would actually be higher than estimated by Charlwood (approximately 51\%).

Terzian and Stahler [76] considered that the malefemale composition of a mosquito population may influence feeding behavior, after a laboratory study with $A n$. quadriannulatus in which the virgin females never took a blood meal. This supports the hypothesis that take-off or host-seeking behavior is inhibited until a substance is transmitted to the female during mating. Recent studies on the behavior of several other anopheline species show that pre-gravid biting is common and sometimes needed before mating can occur $[77,78]$. Multiple blood meals 
Table 1 Categorical overview of breeding sites of An.darlingi

\begin{tabular}{llc}
\hline $\begin{array}{l}\text { Breeding site } \\
\text { category }\end{array}$ & Breeding site characteristics & References \\
\hline Lakes and Lagoons & in lake side vegetation and floating debris, in more exposed deeper parts of the lakes & {$[2,3,7,10,57,91,128,142]$} \\
Large rivers & $\begin{array}{l}\text { Semi-shaded, along the river edges, between floating debris and superficial vegetation, sections with } \\
\text { slow water flow }\end{array}$ & {$[2,3,9,21,42,63,66]$} \\
Small rivers & Slow flow rivers, creeks, residual pools in riverbeds during the dry season, irrigation canals & {$[7,46,57,101,143]$} \\
Flooded forest & Flooded forested riversides in the rainy season, swamps & {$[2,7,57,63,91,144]$} \\
Small water & Ditches, drains, wells, rain pools, old, abandoned (mining) pits & {$[2,3,10,57,145]$} \\
collections & & {$[2,3,21,64,71]$} \\
Rare breeding sites & Fully shaded water bodies, very small water collections, brackish or acid water, polluted water & \\
\hline
\end{tabular}

within a single gonotrophic cycle appear to be less important in the life histories of neotropical Nyssorhynchus species, including $A n$ darlingi, compared to Afrotropical malaria vectors. One blood meal is usually enough for egg maturation $[79,80]$.

Age of female mosquitoes is estimated from the parity rate of a population, i.e. the rate of females which have had a blood meal and have laid eggs (as determined using the ovarian tracheole dissection by Detinova [81]). The reliability of this method, especially in older females is subject to discussion [82]. Age composition of female $A n$. darlingi collected in the field differs over collection time, collection seasons and locality. Higher variability in age composition may be found in the dry season, possibly related to availability of breeding sites and more stable climatic conditions [83]. Hudson [46] found that the parous rates of females he caught in Suriname from 19.00-22.00 h were 10-20\% higher than those of females caught at other times of the night. The differences in age composition over season and time of day or night will need to be taken into account when collecting the mosquitoes for determination of infection rate [84]. Age composition may also depend on the distance of breeding sites to nearby human settlements. More gravid females and less nulliparous females are found close to breeding sites than in villages away from breeding sites [85].

Flight range of malaria vectors is an important determinant for their success in transmission over distance. Deane et al. [2] found breeding sites as far as 1.5 to $2 \mathrm{~km}$ from the sites of adult captures in the Amazon. In a study in Jardim das Copaíbas (Roirama, Brazil) Monteiro de Barros et al. [80] found that $20.3 \%$ of $A n$. darlingi would fly over $500 \mathrm{~m} ., 4.6 \%$ would fly over $1000 \mathrm{~m}$., and less than 1\% further than $1200 \mathrm{~m}$. In comparison, Achee et al. [86] found recovery rates of $29 \%, 11.6 \%, 5.8 \%$ at distances of 0, 400 and 800 m., respectively, in Belize. Tadei [7] estimates a possible flight range of $5 \mathrm{~km}$ when going downwind, and Charlwood and Alecrim [87] in a capture-recapture study in Brazil found two $A n$. darlingi females at $7.2 \mathrm{~km}$. from their release site, nine days after release. Recapture rate at the release site was $12-19 \%$.
This dispersal behavior is similar to what is found in African anopheline species [88]. Due to the variability of the vectorial capacity determinants and their dependence on external factors vectors, obtaining insight into local $A n$. darlingi vectorial capacity is difficult and requires a sound methodology and understanding of the variabilities.

\section{Relative abundance and feeding behavior}

Anopheles darlingi is attracted to the human host $[57,87,89]$. Deane et al. [2] and Rachou [3] compared the attraction of the mosquitoes to humans and other mammals and found that especially humans and large mammals, like horses, are preferred. Zimmerman et al. [89] considered that host selection may in fact vary much depending on host availability and can differ significantly in different sites within one region. The tendency of $A n$. darlingi to go indoors for biting was confirmed very early $[2,90,91]$. A study in Belize showed an indoor-outdoor ratio of 1:0.6 for An. darlingi [25]. In Brazil a larger degree of variation in behavior was found by Deane et al. [2], who discovered a stronger exophilic tendency in the Interior of Brazil. Charlwood [37] confirmed this with his study in Manaus, where he found $A n$. darlingi to be primarily exophagic and exophilic, while in northern Brazil (towards the border with Guyana and Venezuela) it was more endophagic. Rozendaal [92] captured 73\% of the $A n$. darlingi in the Interior of Suriname outside of the houses, in the peridomestic areas. He discovered that, even when $A n$. darlingi is anthropophilic and prospers in the presence of human blood, it is able to survive as a 'wild' population in much lower numbers on animal blood. This was also found in French Guyana by Pajot [93], and in Brazil by Deane et al. [2] where An. darlingi was collected in uninhabited areas.

Elliot [58] found that in periods of increased mosquito density the relative importance of outdoor biting (during times of human activity) declines. He offers two possible explanations, the first one being that in periods of highest density the females may have a $48 \mathrm{hr}$ gonotrophic cycle, causing them to lay eggs in the early evening and start feeding in the late night of the same night. The second 
explanation would be that high density of mosquitoes often coincides with periods of heavier rainfall and higher relative humidity. Relative humidity inside houses, which may well inhibit entry when it is low in the first hours after sunset, would rise sooner in the wet season as the house cools, which may result in higher numbers of entry. Either or both hypotheses could be true. Hudson [46] studied the resting time of mosquitoes before and after biting in Suriname and found at Aselikamp in June 1979 that the mean resting periods observed were 7.7 min (range 1-35) for 52 unfed females, and $17.1 \mathrm{~min}$ (range 2-41) for 10 blood fed females.

Biting cycles of An. darlingi seem to differ significantly between various regions of its distribution area, and even in localities not far apart. Some studies record unimodal [94] and other bimodal biting rythms $[1,7,42,59,95]$. Da Silva-Vasconcelos [71] found no defined biting peak for An. darlingi in Boa Vista (Roraima, Brazil) where over 10\% of the anopheline population was found to be An. darlingi and where An. darlingi had the highest Plasmodium infection rate and together with An. albitarsis was considered the prime vector for this area. Forattini [1] found that the distribution of the 9,523 An. darlingi caught in southern Brazil at 1500 feet displayed a distinct bimodal distribution in the daily blood feeding periodicity with peaks at both dusk and dawn. Hudson [46] discovered that biting cycles of An. darlingi at his two study sites (Aselikamp and Apoma Tapoe, Suriname) showed a single main peak, but the peak would occur one hr later at Aselikamp (22.0023.00) than at Apoma Tapoe (21.00-22.00), with smaller secondary peaks at 18.00-19.00 and 5.00-6.00 hr. Pajot et al. [42] found a trimodal cycle in nearby French Guiana, including both twilight periods and a clear nocturnal peak between 1.00-2.00. He also found that cycles of biting activity of parous and nulliparous females are similar, both inside the house and on the veranda. That different biting cycles of An. darlingi can be found in a single locality over the seasons was discovered by Leon et al. [96] in St Clara (Peru) where a unimodal cycle was found from August to December and a bimodal cycle from January to June. Vector control activities like Indoor Residual Spraying (IRS) or the use of insecticide treaded nets (ITNs) can result in a change in biting behavior [96-98].

Lunar cycles do not appear to influence daily biting rhythms of most mosquito species, but larger numbers of mosquitoes can be collected during new moon [99]. Voorham [100] discarded the likelihood of mosquito density interfering with biting behavior after his study in the State of Amapa (Brazil), this is consistent with studies in for instance French Guiana [42], but is not in line with results obtained in studies in Colombia and Brazil [101]. Voorham acknowledges that intra-population variation of biting activity can be as significant as inter-population variation, and states that plasticity in biting activity patterns can result in increased vectorial potential of mosquitoes and control strategies may have to be adjusted to account for difference in human-vector contact over time.

Mosquitoes may very well display a preference in their biting sites on their available or preferred host. Observations by De Jong and Knols [102] on mosquito biting on humans revealed that many species have preferred biting sites, and that not all species share the same preferences. Selection of these sites may be related to several factors, depending on the mosquito species, including visual and chemical properties of the host. This was confirmed by the differential attractiveness of Kenyan men to the African malaria vector An. gambiae [103] and another study that revealed that allomonal breath contributes to differential attractiveness of humans to the African malaria vector An. gambiae [104]. In a study on the South American malaria vector $A n$. albimanus, biting sites were recorded mostly from the head region, suggesting that this species responds mostly to human breath [105]. Studies on biting site preferences of An. darlingi are necessary to provide information on cues that are important in the finding and selection of a host. This information could be applied in trapping and control activities [106].

\section{Biological variation}

The possibility that the mosquito species $A n$. darlingi may consist of a species complex is subject of continued research. If true, it could have important implications for future malaria control schemes in Latin America. Charlwood [37] found that An. darlingi mosquitoes from the Manaus area are more chromosomically diverse than mosquitoes towards the northern edge of the distribution area (Venezuela and Guyana). He also found that female wing size can vary between populations. Wing size variation in mosquitoes can in fact be due to other than genetic variation, for instance to differences in larval population densities and food availability, as was shown for Aedes aegypti by Jirankanjanakit et al. [107]. A study by Harbach et al. [108] showed that the An. darlingi specimens found in Belize show variation in their hind tarsal markings at a more than incidental rate.

Rosa-Freitas et al. [109] related iso-enzymatic, behavioral and mitochondrial DNA studies on Brazilian and other Latin-American populations and deducted that An. darlingi is a monotypic species. Mirabello and Conn [110] studied the genetics of An. darlingi mosquitoes to determine whether there is a division in the gene pool between Central and South America and found no significant evidence for this. Conn et al. [111] continued this research in an attempt to find a population bottleneck in An. darlingi due to possible pressure as a result of insecticide use. The bottleneck was not found but significant differentiation between locations north and south of the Amazon River 
were discovered, suggesting a degree of genetic isolation between them, which was attributed to isolation by distance. Continued studies by Mirabello et al. [112] result in the conclusion that "all of the data confirm a deep divergence between Amazonia and southern Brazil (genotype 1), and Central America, Colombia, and Venezuela (genotype 2).", which indicate incipient speciation. Recent studies in Brazil and Colombia show that on a more local level speciation is less likely due to high levels of gene flow, although even on that level evidence for isolation by distance exists [113,114].

\section{Ecological change}

In the whole of South America ongoing development results in changing environments: agriculture and industries, colonization of uninhabited areas by humans, construction of hydropower dams, and forestry and mining activities are some of the causes. The globally changing climate is another. Change of ecosystems can result in a change in availability of breeding sites for mosquitoes or a change of survival rate and reproduction $[115,116]$. This may affect the malaria transmission risk. According to Patz \& Olson [117], changing temperature trends, due to influences from global climate change and local land use practices, may alter malaria risk, due to 1 ) a shift in time needed for parasite development, 2) changing mosquito abundance and survivorship, 3) a change in gonotrophic cycle, and 4) a change in larval development and pupation rates. Non-sustainable forestry, resulting in large-scale deforestation, will have an effect on local temperature, and possibly on the availability of breeding sites. Vittor [118] found that the biting rate of An. darlingi is positively related to the amount of deforested land, and further found that deforested sites had an Anopheles darlingi biting rate that was more than 278 times higher than the rate determined for areas predominantly forested [119]. In accordance, Harris et al. [120] considered that the growing malaria problem in the Bolivian Amazon (a four-fold increase between 1991 and 1998) was largely due to forest clearance, bringing human and vector populations into closer contact. Malaria outbreaks were predicted for Belem (Brazil) as a result of the continued expansion of the city into the surrounding forest in the 1990s, and the observed increase in the population sizes of An. darlingi in these locations [121].

The construction of hydropower dams often came with special awareness of a possible increase of the malaria risk, which resulted in related studies. De Carvallo [122] found a decline in An. darlingi densities and malaria transmission after the construction of the Lages dam in Brazil. This was attributed to the variations in water level, which destroyed the preferential breeding places of An. darlingi. Rozendaal [63] found that, in contrast to the prediction by Van Thiel [123], the hydropower scheme which created Van Blommenstein lake in 1971 in Suriname, did not cause a malaria problem. No An. darlingi were found in that area. He assumed that the non-shaded shores of the lake are unsuitable breeding habitats. With the completion of the (binational) Itaipu dam between Brazil and Paraguay and the maintenance of the breeding places for An. darlingi an increasing number of malaria cases, especially in the Upper Parana River, was expected. Falavigna-Guilherme et al. [9] describe the occurrence of some $P$. vivax outbreaks after the completion of the dam, but believe that with the adoption of satisfactory preventive measures, including health educational and social actions, malaria can be controlled. Zeilhofer et al. [124] found a positive relationship between the An. darlingi presence and increased proximity to forested areas near reservoirs, especially in bays protected from wind and wave action. Breeding site classification with satellite imaging together with entomological studies are proposed as a valuable tool for spatial modeling of An. darlingi habitats in hydropower reservoir areas [124].

One increasingly common human activity in South America is gold mining, especially in the forested areas of the Amazon. The relation between gold mines and malaria has been discussed often [125]. In fact, the reemergence of $P$. falciparum malaria in Cuyuni-MazaruniPotaro in Guyana, after 28 years of absence of cases, was considered due to the 'gold rush' [126]. In Mato Gross (Brazil) a positive correlation existed between amount of gold extraction and malaria incidence rate [127]. Very early on it was recognized that in mining areas, old abandoned pits could be suitable as Anopheles breeding sites [57] and this was recently re-established [13]. Clear and deep water bodies remain after sand and debris are deposited on the bottom of the mining pits over time. Destruction of the surrounding forest by the mining activities may result in less than optimal amount of shadow, but An. darlingi has shown tolerance to high water temperatures [41] and an ability to adapt. Following a successful malaria intervention program in the Interior of Suriname between 2005 and 2010, the only persistent malaria areas are associated with gold mines (H. Hiwat, unpublished results).

\section{Surveillance and Control}

Capturing An. darlingi is not easy. So far, human landing catches seem the 'golden standard' for collecting this vector. The generally disappointing results of various trapping devises when compared to human landing collections (see for instance Moreno et al. [39], Brochero et al. [128], Turrel et al. [129], Dusfour et al. [130]) may lie in the high degree of anthropophily which is often found in this species. This high degree of anthropophily could indicate that $A n$. darlingi is attracted by very 
specific human-related cues, and is therefore less inclined to enter traps which fail to present these cues. Since human landing catches are costly and labor-intensive and may present a risk to the collector, alternative methods are needed. Further studies into the biting behavior and preferences of $A n$. darlingi may be instrumental in the development of an efficient alternative collecting method which can be used in vector surveillance. Identifying the host-related cues which attract the vector can ultimately result in more target-specific control measures. This line of study and tool development is currently employed for An. gambiae s.s. surveillance and control [131].

Evidence exists that vector control measures can result in changing characteristics of the targeted vector [132]. Long-term DDT use resulted in a changed susceptibility of An. darlingi populations over time [133]. Indoor Residual Spraying (IRS) and Insecticide Treated Nets (ITNs) reduced intra-domiciliary vector densities in several species and variation in biting time after their introduction has been recorded [134,135]. Which vector control method to use at a certain location, depends very much on the characteristics of the vector and requires adequate baseline information and continuous monitoring to detect changes [136]. ITNs for instance proved very successful against $A n$. darlingi in southern Venezuela, where a reduction of $56 \%$ of malaria cases was recorded in local indigenous populations after the introduction of lambdacyhalotrin-treated hammock nets [137]. The use of same ITNs in the Bolivian Amazon might be less successful because, as Harris et al. [120] found, $48 \%$ of mosquito biting takes place between 19.00 and 21.00 h., when most people are not yet in the protective area of the net.

The mobility of larval mosquitoes is low compared to that of the adult forms, which is why larval control of vectors can be a powerful tool in malaria control [138]. Possible options are biological control with larvivorous fish or bacteria, or chemical control, for instance with oil. Whether larval control can be successful depends on the characteristics, especially the size, of breeding habitats [139]. Anopheles darlingi breeds in various habitats, smaller and larger, often covering wide areas (see above). In clearly defined breeding sites, like the stagnant water bodies remaining after the rainy season, limited areas of swamps or inundated forest floors, and possibly mining pits or other limited breeding sites derived from human activity, larval control with microbial larvicides could be effective. Bacterial control has been successful in Africa when directed at An. gambiae [140], but also in breeding sites in Peru and Equador [141]. The difficulty of localizing the breeding sites where larval control of $A n$. darlingi could be successful to reduce malaria incidence is yet another issue. The Amazon rainforest is still a sparsely inhabited area, and the logistics of locating and treating individual breeding sites may preclude control directed at the larval stage. Satellite imaging may prove a useful tool in this endeavor. Studies on this subject are currently undertaken [124].

\section{Conclusions}

Anopheles darlingi is widely distributed across South America, but the species is especially important as malaria vector in the Amazonian countries. Even though the natural infection rate and population densities of this vector are often low, its efficiency in malaria transmission, through high biting rates and a good susceptibility to Plasmodium infection, is high. Anopheles darlingi is mostly anthropophilic and shows a capacity to adapt to changing environmental situations. Local variability in determinants for the vectorial capacity of $A n$. darlingi is high and many aspects determining this capacity, i.e. its relation to seasons and environmental conditions, its gonotrophic cycle and longevity, and its feeding behavior and biting preferences, are still unknown. This means that the establishment of an effective control strategy will require elaborate studies on the (local) vector situation. Also this behavioral plasticity makes it difficult to predict the impact of changes in ecological environment and in (macro) climate on the vector populations. Adaptation through natural selection is to be expected. This allows the vector to establish populations in areas where it previously did not exist or had been controlled. The behavioral variability of the vector, its adaptability, and our limited knowledge of it impede the establishment of effective control strategies. Increasing our knowledge of An. darlingi, therefore, is necessary.

\section{Acknowledgements}

We are grateful to Prof. Dr. Marcel Dicke and Prof. Dr. Willem Takken for critically reviewing the manuscript.

\section{Author details}

'Laboratory of Entomology, Wageningen University and Research Centre, PO Box 8031, 6700 EH Wageningen, The Netherlands. 'Malaria Program, Ministry of Health Suriname, c/o Bureau of Public Health Suriname, Rode Kruislaan

13, Paramaribo, Suriname. ${ }^{3}$ Calle Dalia 20 los Parques, Los Ceibos, Guayaquil, Ecuador.

\section{Authors' contributions}

$\mathrm{HH}$ conceived and wrote the article. GB helped with its design and content. Both authors read and approved the final manuscript.

\section{Competing interests}

The authors declare that they have no competing interests.

Received: 6 July 2011 Accepted: 16 September 2011

Published: 16 September 2011

\section{References}

1. Forattini OP: Compartemento exofilo de Anopheles darlingi Root, em regiảo meridional do Brasil. Exophilic Behavior of Anopheles darlingi Root in a southern region of Brazil. Rev Saúde Publ 1987, 21:291-304. 
2. Deane LM, Causey OR, Deane MP: Notas sôbre a distribuição e a biologia dos anofelinos das regiões nordestina e amazônica do Brasil. Rev Serv Espec Saude Publ 1948, 1:827-965.

3. Rachou RG: Anofelinos do Brasil. Comportamento das species vetoras de malaria. Rev Braz Malariol Doenças Trop 1958, 10:145-181.

4. Komp WHW: The occurrence of Anopheles darlingi Root in Central America. Am J Trop Med Hyg 1941, 21:659-670.

5. Moutinho PR, Gil LHS, Cruz RB, Ribolla PEM: Population dynamics, structure and behavior of Anopheles darlingi in a rural settlement in the Amazon rainforest of Acre, Brazil. Malar J 2011, 10:174.

6. Giglioni G: Biological variations in Anopheles darlingi and Anopheles gambiae. Their effect on practical malaria control in the Neotropical Region. Bull World Health Org 1956, 15:461-471.

7. Tadei WP, Santos JMM, Costa WLD, Scarpassa VM: Biologia dos Anopfelinos Amazônicos, Occorência de Espécies de Anopheles, Dinâmica da Transmissão e Controle da Malária na Zona urbana de Ariquemes (Rondônia). Ver Inst Med Trop Sâo Paolo 1988, 30:221-251.

8. Sinka ME, Rubio-Palis Y, Manguin S, Patil AP, Temperley WH, Gething PW, Van Boeckel T, Kabaria CW, Harbach RE, Hay SI: The dominant Anopheles vectors of human malaria in the Americas: occurrence data, distribution maps and bionomic Precis. Parasites and Vectors 2010, 3:72.

9. Falavigna_Guilherme AL, Da Silva AM, Guilherme EV, Morais DL: Retrospective study of malaria prevalence and Anopheles genus in the area of influence of the binational itaipu reservoir. Rev Inst Med Trop S Paulo 2005, 47:81-87.

10. Forattini OP: Entomología médica, vol I. Parte Geral, Diptera, Anophelini. Sao Paolo, Faculdade de Higiene e Saude Publica Universidade de Sao Paolo; 1962.

11. Aramburú J, Ramal C, Witzig R: Malaria Reemergence in the Peruvian Amazon Region. Emerg Infect Dis 1999, 5:209-215.

12. Flores-Mendoza C, Fernández R, Escobedo-Vargas KS, Vela-Perez Q, Schoeler GB: Natural Plasmodium Infections in Anopheles darlingi and Anopheles benarrochi (Diptera: Culicidae) from Eastern Peru. J Med Entomol 2004, 41:489-494.

13. Moreno JE, Rubio-Palis Y, Páez E, Pérez E, Sánchez V: Abundance, biting behavior and parous rate of anopheline mosquito species in relation to malaria incidence in gold mining areas of Southern Venezuala. Med Vet Entomol 2007, 21:339-349.

14. United Nations: We can end poverty 2015: Millennium Development Goals. 2010 [http://www.un.org/millenniumgoals/].

15. Ferguson HM, Dornhaus A, Beeche A, Borgemeister C, Gottlieb M, Mulla MS, Gimnig JE, Fish D, Killeen GF: Ecology: A prerequisite for Malaria Elimination and Eradication. PLOS Med 2010, 7(8):e1000303.

16. MalERA Consultative Group on Vector Control: A Research Agenda for Malaria Eradication: Vector Control. PLoS Med 2011, 8(1):e1000401.

17. World Health Organization: World Malaria Report 2010. 2010 [http://www. Who.int/malaria/world_malaria_report_2010/en/index.html].

18. Manguin S, Carnevale P, Mouchet J, Coosemans M, Julvez J, RichardLenoble D, Sircoulon J: Biodiversity of malaria in the world. Montrouge, France, John Libbey Eurotext 2008.

19. Santamarina Mijares A, Pérez Pacheco R, Tomás Martínez SH, Enrique Cantón L, Flores Ambrosio G: The Romanomermis iyengari parasite for Anopheles pseudopunctipennis suppression in natural habitats in Oaxaca State, Mexico. Rev Panam Salud Publica 1999, 5:23-28.

20. Loyola EG, Arrendondo Jl, Rodriguez MH, Browns DN, Vasa Marin MA: Anopheles vestitipennis, the probable vector of Plasmodium vivax in the Lacandon forest of Chiapas, Mexico. Trans Roy Soc Trop Med Hyg 1991, 85:171-174.

21. Manguin S, Roberts DR, Andre RG, Rejmankova E, Hakre S: Characterization of Anopheles darlingi (Diptera: Culicidae) larval habitats in Belize. J Med Entomol 1996, 33:205-211.

22. Shah S: The battle against malaria; turning away from DDT to greener weapons.[http://www.worldchanging.com/archives/011134.html].

23. Mirabello L, Conn JE: Molecular population genetics of the malaria vector Anopheles darlingi in Central and South America. Heredity 2006, 96:311-321.

24. Hernandez MM, Recinos MG, Salazar V, Flores R, Rodas A: Variacion Metrica inter e intrasepcifica en mosquitos del genero Anopheles vectores de la malaria en Guatamala. San Carlos, Direccion General de Investigation Universidad de San Carlos de Guatamala 2009.
25. Roberts DR, Manguin S, Rejmankova E, Andre R, Harbach RE, Vanzie E, Hakre S, Polanco J: Spatial distribution of adult Anopheles darlingi and Anopheles albimanus in relation to riparian habitats in Belize, Central America. J Vector Ecol 2002, 27:21-30.

26. Roberts DR, Chan O, Pecor J, Rejmankova E, Manguin S, Polanco J, Legers J: Preliminary observations on the changing roles of malaria vectors in southern Belize. J Am Mosa Contr Assoc 1993, 9:456-459.

27. Kumm HW, Ram LM: Observations on the Anopheles of British Honduras. Am J Trop Med Hyg 1941, 21(Suppl 1):559-566.

28. Almendares J, Sierra M, Anderson PK, Epstein PR: Critical conditions; a profile of Honduras. The Lancet 1993, 342:1400-1402.

29. Garfield R: Malaria control in Nicaragua: social and political influences on disease transmission and control activities. The Lancet 1999, 354:414-418.

30. PATH: Malaria in Nicaragua. A review of control status trends and needs. 2010 [http://www.path.org/files/TS_nicaragua_malaria_rpt.pdf].

31. Centers for Disease Control and Prevention: Health Information of International Travel 2010.[http://wwwnc.cdc.gov/travel/content/ yellowbook/home-2010.aspx].

32. Dehné EJ: Fifty years of malaria control in the Panama area. Am J Trop Med Hyg 1955, 4:800-811.

33. Loaiza JR, Bermingham E, Scott ME, Rovira JR, Conn JE: Species Composition and distribution of adult Anopheles (Diptera; Culicidae) in Panama. J Med Entomol 2008, 45:841-851.

34. Loaiza JR, Scott M, Bermingham E, Rovira JR, Sanjur O, Conn JE: Short Report: Anopheles darlingi (Diptera: Culicidae) in Panama. Am J Trop Med Hyg 2009, 81:23-26.

35. Olana VA, Brochero H, Saenz R, Quinones ML, Molina JA: Mapas preliminaries de la distribution de species de anopheles vectores de malaria en Colombia. Biomedica 2001, 21:402-408.

36. Guttierez LA, Naranjo N, Jaramillo LM, Muskus C, Luckhart S, Conn JE, Correa MM: Natural Infectivity of Anopheles species from the pacific and Atlantic regions of Colombia. Acta Trop 2008, 107:99-105.

37. Charlwood JD: Biological variation in Anopheles darlingi Root. Mem Inst Oswaldo Cruz 1996, 91:391-398.

38. Magris M, Rubio-Palis Y, Menares C, Villegas L: Vector bionomics and malaria transmission in the Upper Orinoco River, Southern Venezuela. Mem Inst Oswaldo Cruz 2007, 102:303-311.

39. Moreno J, Rubio-Palis Y, Pérez E, Sánchaes V, Páez E: Evaluación de tres métodos de captura de anofelinos en un área endémica de malaria del estado Bolivar, Venezuela. Entomotropica 2002, 17:157-165.

40. Rambajan I: Re-appearance of Anopheles darlingi Root 1926 and vivax malaria in a controlled area of Guyana, South America. Trop Geogr Med 1984, 36:61-66.

41. Rozendaal JA: Observations on the biology and behavior of anophelines in the Surinam rainforest. Cah ORSTROM ser Ent Méd et Parasitol 1987, 15:33-43.

42. Pajot F-X, Le Pont F, Molez J-F, Degallier N: Aggressivité d' Anopheles (Nyssorhynchus) darlingi Root, 1926 (Diptera, Culicidae) en Guyane française. Cah ORSTOM ser Ent Méd et Parasitol 1977, 15:15-22.

43. Juminer B, Robin Y, Pajot FX, Eutrope R: Physionomie du paludisme en Guyane. Med Trop 1981, 41:135-146.

44. Girod R, Gaborit P, Carinic R, Issaly J, Fouque F: Anopheles darlingi bionomics and transmission of Plasmodium falciparum, Plasmodium vivax and Plasmodium malariae in Amerindian villages of the Upper Maroni Amazonian forest, French Guiana. Mem Inst Oswaldo Cruz 2008, 103:702-710.

45. Hiwat H, Issaly J, Gaborit P, Somai A, Samjhawan A, Sardjoe P, Soekhoe T, Girod R: Behavioral heterogeneity of Anopheles darlingi (Diptera: Culicidae) and malaria transmission dynamics along the Maroni River, Suriname, French Guiana. Trans R Soc Trop Med Hyg 2009, 104:207-213.

46. Hudson JE: Anopheles darlingi Root (Diptera:Culicidae) in the Surinam rain forest. Bull Ent Res 1984, 74:129-142.

47. Claustre J, Venturin C, Nadiré M, Fauran P: Malarial vectors in French Guiana: study in an epidemic focus near Cayenne (1989-1998). Bull Soc Pathol Exot 2001, 94:353-357.

48. De Arruda M, Carvallo MB, Nussenzweig RS, Maracic M, Ferreira AW, Cochrane AH: Potential vectors of malaria and their different susceptibility to Plasmodium falciparum and Plasmodium vivax in northern Brasil identified by immunoassay. Am J Trop Med Hyg 1986, 35:873-881. 
49. Póvoa MM, Lessa de Souza RT, Da Luz Lacerda RN, Santa Rosa E, Galiza D, De Souza JR, Wirtz R, Schlichting CD, Conn JE: The importance of Anopheles albitarsis $\mathrm{E}$ and An. darlingi in human malaria transmission in Boa Vista, State of Roirama, Brazil. Mem Inst Oswaldo Cruz 2006, 101:162-168.

50. Schoeler GB, Flores-Mendoza C, Fernández R, Reyes Davila J, Zyzak M: Geographical distribution of Anopheles darlingi in the Amazon Basin Region of Peru. J Am Mosq Control Assoc 2003, 19:286-296.

51. Pinedo-Cancino $V$, Sheen $P$, Tarazona-Santos $E$, Oswald WE, Jeri $C$, Vittor $A Y$, Patz JA, Gilman RH: Limited diversity of Anopheles darlingi in the Peruvian AmazonRegion of Iquitos. Am J Trop Med Hyg 2006, 75:238-245

52. Walter Reed Army Medical Center: Disease Vector Ecology Profile Bolivia. Defense Pest Management Information Analysis Center, Washington DC; 1998.

53. De Casa C, Isabel S: Malaria re-infestation on the northern border of Argentina. Geo Journal 1992, 26:65-67.

54. Davis NC: Anopheles pseudopunctipennis as a malaria transmitter in Northern Argentine Republic. Am J Trop Med Hyg 1927, 7:167-176.

55. Juri MJD, Zaidenberg M, Almiron W: Distribución espacial de Anopheles pseudopunctipennis en las Yungas de Salta Argentina. Rev Saude Publ 2005, 39:565-570.

56. Juri MJD, Zaidenberg M, Claps GL, Santana M, Almiron W: Malaria transmission in two localities in northwestern Argentina. Malar J 2009, $8: 18$.

57. Giglioli G: Malaria in British Guiana; part III. Breeding habits of An. darlingi natural factors which limit the distribution of this species and of malaria. Agr J British Guiana 1938, 9:197-206.

58. Elliot R: Studies on Man-Vector contact in some malarious areas in Colombia. Bull World Health Org 1968, 31:239-253.

59. Tineo VE, Medina CA, Fallaque FC, Chávez L, Quispe S, Mercado M, Zevallos J, León W, Palomino M: Distribución geográfica y comportamiento estacional de la picadura del Anopheles (Nyssorhynchus) darlingi Root 1926 en localidades de la frontera PerúBolivia, Madre de Dios, Perú. Rev Perú Med Exp Salud Publica 2003, 20:78-83.

60. León W, Valle J, Naupay R, Tineo E, Rosas A, Palomino M: Comportamiento estacional del Anopheles (Nyssorhynchus) darlingi Root 1962 en localidades de Loreto y Madre de Dios, Peru 1999-2000. Rev Peru Med Exp Salud Publica 2003, 20:22-27.

61. Charlwood JD: Observations on the bionomics of Anopheles darlingi Root (Diptera; Culicidae) from Brazil. Bull Ent Res 1980, 70:685-692.

62. Gil LHS, Tada MS, Katsuragawa TH, Ribolla PEM, Pereira da Silva LH: Urban and suburban malaria in Rondônia (Brazilian Western Amazon) II: perennial transmissions with high anopheline densities are associated with human environmental changes. Mem Inst Oswaldo Cruz 2007, 102:271-276.

63. Rozendaal JA: Relations between Anopheles darlingi breeding habitats, rainfall, river level and malaria transmission rates in the rain forest of Suriname. Med Vet Ent 1992, 6:16-22.

64. Singer BH, Castro MC: Agricultural colonization and malaria on the Amazon Frontier. Ann N Y Acad Sci 2001, 954:184-222.

65. Vittor AY, Pan W, Gilman RH, Tielsch J, Glass G, Shields T, SánchezLozano W, Pinedo W, Salas-Cobos E, Flores S, Patz JA: Linking deforestation to malaria in the Amazon: characterization of the breeding habitat of the principal malaria vector, Anopheles darlingi. Am J Trop Med Hyg 2009, 81:5-12.

66. Achee NL, Grieco JP, Masuoka P, Andre RG, Roberts DR, Thomas J, Briceno I, King $R$, Rejmankova $E$ : Use of remote sensing and geographic information systems to predict locations of Anopheles darlingi-positive breeding sites within the Sibun River in Belize, Central America. Med Entomol 2006, 43:382-92.

67. Oliveira-Ferriera J, de Lourenco de Oliveria R, Teva A, Dean LM, DanielRibeiro CT: Natural Malaria infections in anophelines in Rondonia state, Brazilian Amazon. Am J Trop Med Hyg 1990, 43:6-10.

68. Klein TA, Lima JBP, Tada MS: Comparative Susceptibility of Anopheline Mosquitoes to Plasmodium falciparum in Rondonia, Brazil. Am J Trop Med Hyg 1991, 44:598-603.

69. Alves FP, Gil LHS, Marrelli MT, Ribolla PEM, Camargo EP, Da Silva LHP: Asymptomatic Carriers of Plasmodium spp. as Infection Source for Malaria Vector Mosquitoes in the Brazilian Amazon. J Med Entomol 2005, 42:777-779.
70. Schneider P, Bousema T, Gouagna LC, Otieno S, Van de Vegte-Bolmer M, Omar SA, Sauerwein RW: Submicroscopic Plasmodium falciparum gametocyte densities frequently result in mosquito infection. Am J Trop Med Hyg 2007, 76:470-474.

71. Da Silva-Vasconcelos A, Neves Kató MY, Neves Mourao E, Lessa de Souza RT, Da Luz Lacerda R, Sibajev N, Tsouris P, Póvoa MM, Momen H, Rosa-Freitas MG: Biting Indices, Host-seeking Activity and Natural Infection Rates of Anopheline species in Boa Vista, Roraima, Brazil, from 1996-1998. Mem Inst Oswaldo Cruz 2002, 97:151-161.

72. Taylor LH: Infection rates in, and the number of Plasmodium falciparum genotypes carried by Anopheles mosquitoes in Tanzania. Ann Trop Med Parasit 1999, 93:659-662.

73. Gillies MT, Wilkes TJ: A study of the age-composition of populations of Anopheles gambiae Giles and Anopheles funestus Giles in North-eastern Tanzania. Bull Ent Res 1965, 56:237-262.

74. Charlwood JD, Wilkes TH: Studies on the age-composition of samples of Anopheles darlingi Root (Diptera: Culicidae) in Brazil. Bull Entomol Res 1979, 69:337-342.

75. Roberts DR, Alecrim WD, Tavares AM, McNeill KM: Field observations on the gonotrophic cycle of Anopheles darlingi (Diptera: Culicidae). J Med Entomol 1983, 20:189-192.

76. Tersian LA, Stahler N: The effect of larval population density on some laboratory characteristics of Anopheles quadriannulatus Say. J Parasitol 1949, 35:487-495.

77. Charlwood JD, Pinto J, Sousa CA, Ferreira C, Gil V, Do Rosario VE: Mating does not affect the biting behavior of Anopheles gambiae from the Islands of Sao Tomé and Principe, West Africa. Ann Trop Med Parasit 2003, 97:751-756.

78. Takken W, Costantini C, Dolo G, Hassanali A, Sagnon F, Osir E: Mosquito Mating Behaviour.[http://www.library.wur.nl/frontis/disease_vectors/ 17_takken.pdf].

79. Lounibos LP, Lima DC, Lourenço-de-Oliveira R, Escher RL, Nishimura N: Egg maturation in neotropical malaria vectors: one blood meal is usually enough. J Vector Ecology 1998, 23:195-201.

80. Monteiro de Barros FS, Honório NA: Man biting rate seasonal variation of malaria vectors in Roraima, Brazil. Mem Inst Oswaldo Cruz 2007, 102:299-302.

81. Detinova TS: Age-grouping methods in Diptera of medical importance with special reference to some vectors of malaria. WHO Monogr 1962, 47:1-216.

82. Hoc TQ, Charlwood JD: Age determination of Aedes cantans using the ovarian oil injection technique. Med Vet Entomol 1990, 4:227-233.

83. Monteiro de Barros FS, Arruda ME, Vasconcelos SD, Luitgards-Moura JF, Confalonieri U, Rosa-Freitas MG, Tsouris P, Lima-Camara TN, Honório NA: Parity and age composition for Anopheles darlingi Root (Diptera: Culicidae) and Anopheles albitarsis Lynch-Arribálzaga (Diptera: Culicidae) of the northern Amazon Basin, Brazil. J Vector Ecology 2007, 32:54-68.

84. Tadei WP, Dutary-Thatcher B: Malaria vectors in the Brazilian Amazon: Anopheles of the subgenus Nyssorhynchus. Rev Inst Med Trop São Paulo 2000, 42:87-94.

85. Ulloa A, Rodriguez MH, Rodriguez AD, Roberts DR: Comparison of two collection methods for estimating abundance and parity of Anopheles albimanus in breeding sites and villages of southern Mexico. J Am Mosq Control Assoc 1997, 13:238-244.

86. Achee NL, Grieco JP, Andre RG, Rejmankova E, Roberts DR: A mark-releaserecapture study using a novel portable hut design to define the flight behavior of Anopheles darlingi in Belize, Central America. J Am Mosa Control Assoc 2005, 21:366-379.

87. Charlwood JW, Alecrim WA: Capture-recapture studies with the South American malaria vector Anopheles darlingi, Root. Ann Trop Med Parasitol 1989, 83:569-576.

88. Takken W, Charlwood JD, Billingsley PF, Gort G: Dispersal and survival of Anopheles funestus and A gambiae s.l. (Diptera: Culicidae) during the rainy season in southeast Tanzania. Bull Entomol Res 1998, 88:1-6.

89. Zimmerman RH, Ribeiro Calardo AK, Lounibos LP, Arruda M, Wirtz R: Bloodmeal Hosts of Anopheles species (Diptera: Culicidae) in a Malariaendemic area of the Brazilian Amazon. J Med Entomol 2006, 43:947-956.

90. Shannon RC: Anophelines of the Amazon Valley. Proc Entomol Soc Washington 1933, 35:117-143. 
91. Galvao ALA, Damasceno RG, Marques AP: Algumas observações sobre a biologia dos anofelinos de importância epidemiológia em Belém. Pará Arq Hig (Rio de Janeiro) 1942, 12:51-111.

92. Rozendaal JA: Biting and resting behavior of Anopheles darlingi in the Suriname rainforest. J Am Mosq Control Assoc 1989, 5:351-358.

93. Pajot FX, Molez JF, Le Pont F: Anopheles et paludisme sur le HautOyapock (Guyane francaise). Cah ORSTOM ser Entomol Med et Parasitol 1978, 16:105-111.

94. Elliot R: The influence of vector behavior on malaria transmission. Am J Trop Med Hyg 1972, 21:755-763.

95. Lourenço-de-Oliveira R, Da Gana Guimarães AE, Arlé M, Fernández de Silva T, Conçalves Castro M, Albuquerque Motta M, Deane LM: Anophelin species, some of their habits and relation to malaria in endemic areas od Rondõnia state, Amazon region of Brazil. Mem Inst Oswaldo Cruz 1989, 84:501-514.

96. León W, Valle J, Naupay R, Tineo E, Rosas A, Palomino M: Comportamiento estacional del Anopheles (Nyssorhynchus) darlingi Root 1926 en localidades de Loretao y Madre de Dios, Peru 1999-2000. Rev Peru Med Exp Salud Pública 2003, 20:22-27.

97. Bustamante FM: Considerações sôbre sertos problemas especiais relacionados com a erradicação da malária no Brasil. Rev Bras de Malariol Doenças Trop 1959, 11:9-17.

98. Takken W: Do insecticide-treated bed nets have an effect on malaria vectors? Trop Med Int Health 2002, 7:1022-1030.

99. Guimarães AE, Gentile C, Lopes CM, Pinto de Mello R: Ecology of Mosquitoes (diptera: Culicidae) in area of Serra do Mar State Park, State of São Paulo, Brazil. III-Daily biting rhythms and lunar cycle influence. Mem Inst Oswaldo Cruz 2000, 95:753-760.

100. Voorham J: Intra-population plasticity of Anopheles darlingi's (Diptera, Culicidae) biting activity patterns in the state of Amapá, Brazil. Rev Saude Publica 2002, 36:75-80.

101. Tadei WP, Thatcher BD, Santos JMM, Scarpassa VM, Brandão Rodrigues I, Rafael MS: Ecological observations on Anopheline vectors of malaria in the Brazilian Amazon. Am J Trop Med Hyg 1998, 59:325-345.

102. De Jong R, Knols BGJ: Selection of biting sites by mosquitoes. In Olfaction in Mosquito-Host Interactions. Edited by: Bock GR, Cardew G. New York: John Wiley; 1996:89-108.

103. Mukabana WR, Takken W, Coe R, Knols BGJ: Host-specific cues cause differential attractiveness of Kenyan men to the African malaria vector Anopheles gambiae. Malaria Journal 2002, I:17.

104. Mukabana WR, Takken W, Killeen GF, Knols BGJ: Allomonal effect of breath contributes to differential attractiveness of humans to the African malaria vector Anopheles gambiae. Malaria Journal 2004, 3:1.

105. Knols BJG, Takken W, De Jong R: Influence of human breath on selection of biting site by Anopheles albimanus. J Am Mosa Control Assoc 1994, 10:423-426.

106. Hiwat H, De Rijk M, Andriessen R, Koenraadt CJM, Takken W: Evaluation of Methods for Sampling the Malaria Vector Anopheles darlingi (Diptera, Culicidae) in Suriname and the Relation with its Biting Behavior. J Med Entomol.

107. Jirakanjanakit N, Leemingsawat $\mathrm{S}$, Thongrungkiat $\mathrm{S}$, Apiwathnasorn $\mathrm{C}$, Singhaniyom S, Bellec C, Dujardin JP: Influence of larval density or food variation on the geometry of the wing of Aedes (Stegomyia) aegypti. Trop Med Int Health 2007, 12:1354-1360.

108. Harbach RE, Roberts DR, Manguin S: Variation in the hindtarsal markings of Anopheles darlingi (Diptera; Culicidae) in Belize. Mosquito Systematics 1993, 25:192-197.

109. Rosa-Freitas MG, Lourenço-de-Oliveira R, De Carvalho-Pinto CJ, FloresMendoza C, Silva-do-Nascimento TF: Anopheline Species Complexes in Brazil. Current Knowledge of Those Related to Malaria Transmission. Memórias do Instituto Oswaldo Cruz 1998, 93:651-655.

110. Mirabello L, Conn J: Molecular population genetics of the malaria vector Anopheles darlingi in Central and South America. Heredity 2006 96:311-321.

111. Conn JE, Vineis JH, Bollback JP, Onyabe DY, Wilkerson RC, Póvoa MM: Population structure of the malaria vector Anopheles darlingi in a malaria-endemic region of eastern Amazonian Brazil. Am J Trop Med Hyg 2006, 74:798-806.

112. Mirabello L, Vineis JH, Yanoviak SP, Scarpassa VM, Póvoa MM, Padilla N, Achee NL, Conn JE: Microsatellite data suggest significant population structure and differentiation within the malaria vector. Anopheles darlingi in Central and South America. BMC Ecology 2008, 8:3.

113. Scarpassa VM, Conn JE: Population genetic structure of the major malaria vector Anopheles darlingi (Diptera: Culicidae) from the Brazilian Amazon, using microsatellite markers. Mem Inst Oswaldo Cruz 2007, 102:319-27.

114. Gutiérrez LA, Gómez GF, González JJ, Castro MI, Luckhart S, Conn JE, Correa MM: Microgeographic genetic variation of the malaria vector Anopheles darlingi Root (Diptera: Culicidae) from Cordoba and Antioquia, Colombia. Am J Trop Med Hyg 2010, 83:38-47.

115. Giglioli G: Ecological change as a factor in renewed malaria transmission in an eradication area; a localized outbreak of An. aquasalis-transmitted malaria on the Demerara River estuary, British Guiana, in the fifteenth year of An. darlingi and Malaria eradication. Bulletin of the World Health Organization 1963, 29:131-145.

116. Takken W, De Tarso R, Vilarinhos P, Schneider P, Dos Santos F: Effects of environmental change on malaria in the Amazon region of Brazil. In Environmental Change and Malaria Risk Global and Local Implications. Volume 11. Edited by: Bogers RJ, Martens P, Takken W. Wageningen University Research Centre; 2005:113-123[http://library.wur.nl/frontis/ environmental_change/11_takken.pdf].

117. Patz JA, Olson SH: Malaria risk and temperature: Influences from global climate change and local land use practices. PNAS 2006, 103:5635-5636.

118. Vittor AY: Deforestation and Malaria: Associations Between Vegetation, Vector Ecology, and Malaria Epidemiology in the Peruvian Amazon. Dissertation, The Johns Hopkins University 2003, 480.

119. Vittor AY, Gilman RH, Tielsch J, Glass G, Sgields T, Sánchez Lozano W, Pinedo-Cancino V, Patz JA: The effect of deforestation on the human biting rate of Anopheles darlingi, the primary vector of falciparum malaria in the Peruvian Amazone. Am J Trop Med Hyg 2006, 74:3-11.

120. Harris AF, Matias-Arnez A, Hill N: Biting time of Anopheles darlingi in the Bolivian Amazon and implications for control of malaria. Trans R Soc Trop Med Hyg 2006, 100:45-47.

121. Povoa MM, Conn JE, Schlichting CD, Amaral JCOF, Segura MNO, Da Silva ANM, Dos Santos CCB, Lacerde RNL, De Souza RTL, Galiza D, Santa Rosa EP, Wirtz RA: Malaria Vectors, Epidemiology, and the Re-Emergence of Anopheles darlingi in Belem, Para, Brazil. J Med Entomol 2003, 40:379-386.

122. De Carvallo A: Da influencia das variaçoes de nivel $\mathrm{d}^{\prime}$ agua e do DDT sobre a produçao do Anopheles darlingi. Trabalho apresentado ao XI Congresso Brasiliero de Higiene, Curitiba; Arquivos De Higiene E Saude Publica 1953.

123. Van Thiel PH: Malaria problems arising from the construction of a reservoir in the interior of Surinam. Trop Geogr Med 1962, 14:259-278.

124. Zeilhofer P, Dos Santos ES, Ribeiro ALM, Miyazaki RD, Dos Santos MA: Habitat suitability mapping of Anopheles darlingi in the surroundings of the Manso hydropower plant reservoir, Mato Grosso, Central Brazil. International Journal of Health Geographics 2007, 6:7.

125. Silbergeld EK, Nash D, Trevant C, Strickland GT, De Souza JM, Da Silva RSU: Mercury exposure and malaria prevalence among gold miners in Pará, Brazil. Rev Soc Bras Med Trop 2002, 35:421-429.

126. Rambajan I: Reappearance of unprecedented falciparum malaria: 28 years after the last case in the Cuyuni-Mazaruni-Potaro, Guyana, South America. Trop Geogr Med 1988, 40:269-271.

127. Duarte EC, Fontes CJ: Association between reported annual gold mining extraction and incidence of malaria in Mato Grosso-Brazil, 1985-1996. Rev Soc Bras Med Trop 2002, 35:665-668.

128. Brochero HL, Rey G, Buitrago LS, Olano VA: Biting activity and breeding sites of Anopheles species in the municipality villavicencio, Meta, Colombia. J Am Mosa Control Assoc 2005, 21:182-186.

129. Turell MJ, Sardelis MR, Jones JW, Watts DM, Fernandez R, Carbajal F, Pecor JE, Klein TA: Seasonal distribution, biology, and human attraction patterns of mosquitoes (Diptera: Culicidae) in a rural village and adjacent forested site near lquitos, Peru. J Med Entomol 2008, 45:1165-1172.

130. Dusfour I, Carinci R, Gaborit P, Issaly J, Girod R: Evaluation of four methods for collecting malaria vectors in French Guiana. J Eco Entomol 2010, 103:973-976

131. Verhulst NO, Mukabana WR, Takken W, Smallegange RC: Human skin microbiota and their volatiles as odour baits for the malaria mosquito Anopheles gambiae s.s. Entomologia Experimentalis et Applicata 2011, 139:170-179. 
132. Rozendaal JA, Van Hoof JP, Voorham J, Oostburg BF: Behavioral responses of Anopheles darlingi in Surinam to DDT residues on house walls. J Am Mosq Control Assoc 1989, 5:339-350.

133. Suarez MF, Quiñones ML, Palacios JD, Carrillo A: First record of DDT resistance in Anopheles darlingi. J Am Mosq Control Assoc 1990, 6:72-74

134. Santos JB, Dos Santos F, Macêdo V: Variation of anopheles density with deltamethrin-impregnated mosquito nets in an endemic malaria area of the Brazilian Amazon. Cad Saúde Pública 1999, 15:281-292.

135. Pates H, Curtis C: Mosquito behavior and vector control. Annual Review of Entomology 2005, 50:53-70.

136. Ferguson HM, Dornhaus A, Beeche A, Borgemeister C, Gottlieb M, Mulla MS, Gmnig JE, Fish D, Killeen GF: Ecology: A prerequisite for malaria elimination and eradication. PLoS Med 2010, 7(8):e1000303.

137. Magris M, Rubio-Palis Y, Alexander N, Ruiz B, Galván N, Frias D, Blanco M, Lines J: Community-randomized trial of lambdacyhalothrin-treated hammock nets for malaria control in Yanomami communities in the Amazon region of Venezuela. Trop Med Int Health 2007, 12:392-403.

138. Killeen GF, Fillinger U, Knols BGJ: Advantages of larval control for African malaria vectors: Low mobility and behavioral responsiveness of immature mosquito stages allow high effective coverage. Malaria Journal 2002, 1:8.

139. Curtis CF: Control of Malaria Vectors in Africa and Asia. In Radcliffe's IPM World Textbook. Edited by: Radcliffe EB, Hutchison WD. University of Minnesota, St. Paul, MN; 2006:[http://ipmworld.umn.edu].

140. Fillinger U, Knols BGJ, Becker N: Efficacy and efficiency of new Bacillus thuringiensis var. israelensis and Bacillus sphaericus formulations against Afrotropical anophelines in Western Kenya. Tropical Medicine and International Health 2003, 8:37-47.

141. Kroeger A, Horstick O, Riedl C, Kaiser A, Becker N: The potential for malaria control with the biological larvicide Bacillus thuringiensis israelensis (Bti) in Peru and Ecuador. Acta Trop 1995, 60:47-57.

142. Nagm L, Luitgards-Moura JF, Neucamp CD, Monteiro-de-Barros FS, Honorio NA, Tsouris P, Rosa-Freitas MG: Affinity and diversity indices for anopheline immature forms. Rev Inst Med Trop Sao Paulo 2007, 49:309-316.

143. Hayes J, Charlwood JD: Dinamica estacional de una populacao de Anopheles darlingi, numa area endemic de malaria no Amazonas. Acta Amazonica 1979, 9:79-86.

144. Davis NC: A note on the malaria-carrying anophelines in Belém, Pará, and in Natal, Rio Grande do Norte, Brazil. Riv Malar 1931, 10:43-51.

145. Moreno JE, Rbio-Palis Y, Avecedo P: Indentificación de criaderos de anofelinos en un área endémica del estado Bolivar, Venezuela. Bo Malariol San Amb 2000, 40:21-30.

doi:10.1186/1756-3305-4-177

Cite this article as: Hiwat and Bretas: Ecology of Anopheles darlingi Root with respect to vector importance: a review. Parasites \& Vectors 2011 4:177.

\section{Submit your next manuscript to BioMed Central and take full advantage of:}

- Convenient online submission

- Thorough peer review

- No space constraints or color figure charges

- Immediate publication on acceptance

- Inclusion in PubMed, CAS, Scopus and Google Scholar

- Research which is freely available for redistribution 